Van Zyl, HC

Universiteit van die Vrystaat

\title{
Om met nuwe oë na ander te kyk. Lukas-Handelinge oor ' $n$ teologie van respek'
}

\begin{abstract}
To look at other with new eyes. Luke-Acts on a theology of respect
\end{abstract}

This article deals with the topic of a theology of respect from the perspective of LukeActs. Is respect earned or is it a given with being human? First the context within which Luke-Acts communicated is being described. It was a culture of holiness which created stark divisions within Jewish society where some were regarded as more respectable than others in the eyes of God. Luke-Acts' answer to this is to emphasize that God does not distinguish between people. Subsequently various categories of people are treated to show how this principle is being borne out by Luke-Acts: Gentiles, Samaritans, the poor, tax-collectors, women and sinners. The article closes with a few concluding remarks.

\section{INLEIDING}

Hulle sê respek is iets wat verdien moet word. ' $n$ Mens verstaan hierdie sentiment, en binne 'n bepaalde konteks steek daar groot waarheid in. Maar hierdie siening hou ten minste dié gevaar in dat respek selektief toegeken word, slegs aan diegene wat dit volgens ons standaarde en norme verdien, wat daarvoor gewerk het en daarom respek afdwing. Maar wat van die ander wat dit in ons oë nie maak nie? Verdien hulle nie ons respek nie? Kan ons maar van hulle dink, met hulle maak en teenoor hulle optree soos ons wil?

Is dit nie juis hierdie sentiment wat aan die wortel van 'n ongenaakbare en verskeurde samelewing lê nie? Wat maak dat ons onsself die reg toeëien om ander mense name te noem en aan hulle eienskappe toe te dig sodat hulle in ons oë minder mens word, nie ' $n$ reg op bestaan het nie, en nie ons respek verdien nie. Want die bril waardeur jy na ander kyk, is bepalend vir jou optrede teenoor hulle, of jy die ander maar kan misbruik, beroof, verkrag, vermoor, uitbuit, verkleineer, ignoreer, marginaliseer, uitsluit, bespot, ontneem van regte en voorregte, en ... die lys hou nie op nie.

In hierdie artikel wil ek probeer om deur die bril van Lukas-Handelinge na "die ander" te kyk. Uiteraard het hierdie geskrifte in ' $n$ totaal ander milieu gekommunikeer as waarin ons lewe. Tog is die blik wat hulle ons gee op die werklikheid van hulle dag so kragtig, dit lê soveel houdinge en gedragspatrone bloot dat ons nie anders kan as om deur daardie bril ook na ons eie werklikheid te kyk nie. ' $n$ Goeie begrip het immers ' $n$ halwe woord nodig. Hierdie artikel wil dus aantoon hoe respek en gebrek aan respek vir ander algemeen menslike verskynsels is en in bepaalde kulture en tye spesifieke vorme aanneem. Ek wil wys hoe dit in Nuwe-Testamentiese tye gefunksioneer het en watter visie ons vir onsself kan toeëien deur goed na geskrifte soos Lukas-Handelinge te luister.

Uit bogenoemde opmerkings behoort dit duidelik te wees wat met ' $n$ "teologie van respek"

1 In verkorte vorm as referaat gelewer tydens die Teologiese Dag van die Fakulteit Teologie, Universiteit van die Vrystaat, op 2-2-2011. Tema van Teologiese Dag: "Op weg na 'n teologie van respek." 
bedoel word. Die woord "respek" kom van die Latyn, respicere, wat in sy figuurlike aanwending beteken om vir iemand anders agting, ontsag of eerbied te hê (ander Latynse woorde kan ook vir hierdie ingesteldheid gebruik word, soos observare, suspicere en (re)vereri, vgl Simpson 1966:518,815). Respek vir ander kom in alle kulture voor. Maar wat ewe sterk voorkom, is die neiging om onderskeid tref tussen wie respek waardig is en wie nie. En dit is presies op hierdie punt dat ' $n$ teologie van respek 'n ander perspektief na vore bring, naamlik dat God van ons vra om almal met respek te behandel, ongeag wie of wat die ander is. In hierdie verband is dit opmerklik dat die Nuwe Testament ' $n$ uitdrukking wat in die Griekse wêreld gebruik is om ' $n$ respekvolle houding aan te dui, naamlik "om 'n aannemer/eerbiediger van die persoon te wees" (prosōpolēmpsia), op sy kop draai en sê dat dit juis is hoe God nie teenoor mense optree nie. $\mathrm{Hy}$ is nie 'n aannemer van die persoon nie, Hy trek nie sekere mense voor nie (vgl Rom 2:11; Ef 6:9; Kol 3:25; Jak 2:1). Daarmee word die standaard gestel vir ons optrede teenoor mekaar (vgl Lohse 1968:779-780). Ons moet met nuwe oë, met God se oë na ander kyk en eweneens geen onderskeid tref tussen mense nie, ons nie laat verblind deur die ander se (gebrek aan) status nie. En, soos later in die artikel sal blyk, word hiermee sterk aangesluit by gedeeltes in Lukas-Handelinge, soos Hand 10:34-35 en 15:9, wat ons onderwerp stewig anker in die Lukaanse teologie.

Net 'n kort metodologiese opmerking: Nuwe-Testamentici is dit redelik eens dat die Lukasevangelie en Handelinge deur dieselfde outeur geskryf is, ' $n$ narratiewe eenheid vorm en dieselfde oorhoofse teologiese oogmerke het (vgl Tannehill 1990:6-8; Schnelle 2009:463-464). In wese is die twee boeke een geskrif, met twee uitlopers: een wat fokus op die aardse Jesus se bediening in Palestina, en die ander op die verheerlikte Jesus se bediening in die hele destydse wêreld. Hierdie artikel maak dus van beide geskrifte gebruik om die onderwerp uit te bou, hoewel die Lukasevangelie sterker sal figureer.

\section{HEILIGHEIDSKULTUUR AS KOMMUNIKATIEWE KLANKBORD VAN LUKAS-HANDELINGE}

Om die punt wat Lukas-Handelinge wil maak, te snap, is dit nodig om die wêreld waarbinne hy moes kommunikeer, te verstaan. Uiteraard kan mens nie sy totale wêreld skets nie. In hierdie artikel konsentreer ek slegs op een faset van die destydse Joodse samelewing wat vir die onderwerp belangrik is, naamlik die heiligheidskultuur.

'n Mens kan sê dat die eerste eeuse Palestyns-Joodse samelewing deurdrenk was van ' $n$ heiligheidskultuur. In 'n groot mate was dit ook waar van die hele Grieks-Romeinse wêreld om die Middellandse See waarbinne die vroeë kerk geleef het (vgl deSilva 2004:114vv), maar binne die Joodse samelewing in Palestina het dit unieke trekke aangeneem.

Met heiligheidskultuur word bedoel dat streng onderskeid gemaak is tussen die heilige en die profane (deSilva 2004:118vv). Daar is sekere ruimtes, mense, tye en voedselsoorte wat aan God gewy is. Die grense tussen die heilige en die profane moet daarom eerbiedig word; wat heilig is mag nie geprofaniseer word nie. Byvoorbeeld, die allerheiligste in die tempel is die ruimte waar God in die besonder teenwoordig is en dit mag nie deur enigeen betree word nie; slegs die hoëpriester mag dit doen, een maal 'n jaar, en dan op sekere voorwaardes (beskerm deur die bloed van versoening). So is nie-Jode op die tempelterrein beperk tot die voorhof van die heidene (vgl Hand 21:27-29²), en Joodse vroue is uitgesluit van die Israeliete (mans) se voorhof in die tempel (Du Toit 1997a:470).

Met ' $n$ heiligheidskultuur hang ook saam die konsep van rein en onrein. Sekere mense

2 Die situasie hier is waarskynlik dat die Jode gedink het Paulus het vir Trofimus, 'n Griek, in die gedeelte van die tempel ingeneem wat vir die heidene verbode was (Haenchen 1971:616; Lindijer 1990:203; Meier 1965:419). 
(heidene), kossoorte (varkvleis), ruimtes (begraafplase), beroepe (leerlooiers), tye (vroue gedurende die menstruele siklus) is onrein. Daarom is tafelgemeenskap met byvoorbeeld die heidene vermy omdat gemeen is dat hulle, saam met hulle huise, onrein is (vgl Hand 10:28). En as daar toevallige of noodsaaklike kontak plaasgevind het wat besoedeling tot gevolg gehad het, was daar voorgeskrewe reinigingsrituele om weer kulties rein te word ten einde die normale lewe te hervat of weer die heilige ruimtes te mag betree (vgl Mark 7:1-4).

Sekere groepe binne die eerste eeuse Jodedom het die heiligheidskonsep tot die ekstreme gevoer. So het die Esseners en Koemrangemeenskap ${ }^{3}$ hulle letterlik afgesonder van die res van die bevolking ten einde ' $n$ heilige en rein lewe te voer. Hoewel hulle voorbeeldige lewe respek afgedwing het, was hulle invloed beperk. Die Fariseërs daarenteen was 'n gematigder volksbeweging wat groot invloed uitgeoefen het op die breë massa. Hulle was gevul met die visie om van die hele Israel ' $n$ heilige nasie, ' $n$ koninklike priesterdom te maak volgens die ideaal van Eksodus 19:5-6. Anders as die Sadduseërs het die oorleweringe van die vaders vir die Fariseërs gelyke status met die Tora geniet. Hulle het gevolglik die ruimte en vryheid gehad om die Tora vir die daaglikse lewe vrugbaar te maak met eie interpretasies. Dit het met behulp van hulle skrifgeleerdes ${ }^{4}$ geskied. Hierdie praktyk van Skrifuitleg het sy voordele gehad, soos dat die Skrif dinamies in die volkslewe gefunksioneer het, maar ook sy nadele. Die Fariseërs het naamlik probeer om die heilige ruimte van die tempel na die hele volk uit te brei (Van Staden 1991:6). Hierin was die wet van Moses normatief. Die Fariseërs se skrifgeleerdes het gevolglik met noukeurige en spitsvondige Skrifuitleg die Tora op die ganse lewe van die gewone Jood probeer toepas (deSilva 2004:82), met allerlei negatiewe gevolge, soos onder verder verduidelik word.

Die Fariseërs se ywer rondom die Tora het meegebring dat sosiale grense tussen hulle en die res van die volk opgerig is. Weens hulle streng nakoming van die eetvoorskrifte kon hulle nie saam met mense eet wat hierdie voorskrifte nie nagekom het nie (vgl Luk 5:30; 15:1-2). Dit sou die Tora se gesag ondermyn en hulleself onrein maak. Hulle het hulle dus gedistansieer van die "volk van die land" ('am ha'ares), 'n skeldnaam wat so ongeveer "agterlikes" beteken het. Hierdie mense is "sondaars" genoem, dws mense wat nie erns maak met die wet van Moses en, by implikasie, met God nie en so buite die verbond te staan gekom het. Sosiale kontak met die "sondaars" is dus vermy (deSilva 2004:83).

Hierdie heiligheidskultuur het noodwendig ' $n$ diepe verwydering tussen die sg geestelike elite en die res van die religieuse gemeenskap tot gevolg gehad. Die elite het met ' $n$ teologie van eksklusivisme geopereer waarvolgens hulle neergesien ${ }^{5}$ het op almal wat nie aan hulle

3 Baie geleerdes meen dat hierdie twee groepe grootliks oorvleuel het en dat Koemraan essensieel 'n Esseense gemeenskap was (vgl Du Rand 1997:292; deSilva 2004:84).

4 Daar moet soms onderskei word tussen die skrifgeleerdes in die algemeen en die Fariseërs se skrifgeleerdes. Spore van die stryd tussen die vroeë kerk en die Farisese Jodedom is veral sigbaar in die Matteusevangelie. Hartin (1998:399-400) wys bv op die afstand wat Matteus probeer skep tussen die skrifgeleerdes en die Fariseërs, omdat hy juis positief teenoor skrifgeleerdes in eie kerklike geledere staan (vgl Matt 13:52). Hy skep afstand (a) deur in baie gevalle die term "skrifgeleerde" uit die polemiese materiaal te verwyder wat hy uit Markus oorneem en slegs "Fariseërs" te behou, (b) deur te praat van "hulle" skrifgeleerdes (Matt 7:29), en (c) deur die Fariseërs baie negatief te teken (Matt 23). Die feit dat in $1 \mathrm{~g}$ hoofstuk die skrifgeleerdes ook bygekom word, het waarskynlik juis daarmee te make dat dit hier oor die Fariseërs se skrifgeleerdes gaan.

5 Dit spreek vanself dat respek, die keersy van neersien op ander, ook deel van die heiligheidskultuur van destyds was. Byvoorbeeld, dit is duidelik dat die Fariseërs en skrifgeleerdes geteer het op die respek wat aan hulle as "rabbi's," "vaders" en "leiers" betoon is (Matt 23:8-10). Verder, respekvolle resiprositeit was 'n onontbeerlike waarde binne ' $n$ kultuur waar mense van ander se gunste en gawes afhanklik was. Wedersydse uitnodigings na mekaar se maaltye en feeste was dus aan die orde van die dag. Jesus aanvaar dit as vanselfsprekende agtergrond as Hy opmerk dat mens nie jou gelykes na feesmaaltye moet uitnooi nie, maar hulle wat nie aan jou resiprositeit kan bewys nie (Luk 14:12-14). Eers dan beweeg jy in die 
godsdienstige standaarde, praktyke en voorskrifte voldoen het nie. Hulle is as "sondaars" gereken. In hierdie kategorie het selfs mense soos melaatses (gewoonlik diegene met ernstige velsiektes), gestremdes, verminktes (bv eunugs), onreines en onvolmaaktes tereg gekom. Sulke mense is gesien as in die mag van demone en buite die domein van die koninkryk van God (Van Aarde 1994:118).

Die vraag wat vervolgens beantwoord moet word, is hoe Jesus, soos gerapporteer deur Lukas -Handelinge, teenoor hierdie gefikseerde groepe van sy tyd se heiligheidskultuur opgetree het.

\section{LUKAS-HANDELINGE SE ANTWOORD OP DIE HEERSENDE HEILIGHEIDSKULTUUR}

Die rigtinggewende uitspraak van Handelinge 10:34, in samehang met 15:8-9 (kyk ook 1:24), kan as vertrekpunt geneem word om Lukas-Handelinge se vernietigende antwoord op die heersende heiligheidskultuur in die Jodedom van die eerste eeu $\mathrm{nC}$ te illustreer. Handelinge 10 vertel die verhaal van hoe Petrus nuwe oë gekry het oor wie geskik is vir die koninkryk van God en wie nie. Na die gesig op die dak van die huis in Joppe, waar die Here aan hom duidelik gemaak het dat hy nie onrein mag noem wat God rein verklaar het nie, sê Petrus (10:34) dat hy nou verseker weet dat God nie 'n aannemer van die persoon is nie, maar dat enigeen vir God aanvaarbaar is, maak nie saak tot watter volk hy behoort nie. Met "aannemer van die persoon" word bedoel dat God nie volgens uiterlike voorkoms of afstamming oordeel nie, maar die hart aansien, ' $n$ insig wat bevestig word in Hand 15:8-9. Hier noem Petrus God die "hartekenner" wat sy Gees ook aan die heidene gegee het, weer eens 'n verwysing na die epogmakende gebeure in Joppe. En dan voeg hy by dat God geen onderskeid maak tussen nasies nie, maar almal se harte reinig deur geloof. God steur Hom nie aan menslike vooroordele en onderskeidings wat op grond van die uiterlike gemaak word nie, maar Hy kyk tot daar waar dit saak maak - die hart; dáár doen Hy sy reinigingswerk. Opmerklik dat Handelinge hier juis die kategorieë van "rein" en "onrein" gebruik wat binne die heiligheidskultuur van destyds sulke belangrike onderskeidinge was, soos in afdeling 2 verduidelik. Juis hierdie verstikkende kategorieë moes deurbreek word.

Op sy minste moes dit vir Petrus ' $n$ groot verrassing gewees het om tot die ontdekking te kom dat God, die hartekenner, nie onderskeidings in ag neem wat tot in daardie stadium as beklee met Goddelike sanksie gereken is nie. Trouens, verrassings is waaroor Lukas-Handelinge gaan. Soos Hays (1996:133) dit stel: "The unexpected keeps happening in Luke's story." Die onverwagte, verrassende, selfs skokkende, duik om elke hoek en draai op. Wie hom oopstel hiervoor, kan nie anders as om as 'n veranderde mens met nuwe oë na ander te kyk nie.

Ons kyk nou na enkele kategorieë in Lukas-Handelinge wat almal hierdie "ander blik" op die ander weergee, wat so deurslaggewend is vir 'n teologie van respek. Die kategorieë word nie uitputtend bespreek nie; slegs enkele eksemplariese gegewens word aangewend.

\subsection{Die heidene}

Die Jode was gedrenk in die gedagte dat hulle 'n uitsonderingsposisie in die oë van God beklee. Hulle het dit teruggevoer na tekste soos Deuteronomium 4:20 en 7:6 waar staan dat God vir Israel onder al die nasies gekies het en hulle afgesonder ${ }^{6}$ het om vir Hom 'n eiendomsvolk te wees. Hiermee saam word ook 'n teks soos Levitikus 11:44 gelees om die besondere posisie van Israel onder die nasies asook hulle unieke leefwyse te onderstreep: "Wees heilig want Ek is heilig." Hieruit het Israel verkeerdelik afgelei dat hulle beter is as die heidene en dat God die

dampkring van die koninkryk van God. Dit is juis die selektiewe respek van die heiligheidskultuur van sy dag wat Jesus ontmasker wanneer Hy die koninkryk van God se ongekwalifiseerde respek vir mekaar as waarde voorhou.

6 Letterlik: "jy is 'n heilige volk". 
nasies permanent afgeskryf het. Hulle het egter vergeet dat God hulle juis gekies het om sy doel met die hele wêreld te bereik. God sê naamlik aan Abram: "In jou sal al die volke van die aarde geseën wees" (Gen 12:3). Israel moes weer tot hierdie oorspronklike visie teruggeroep word. En dit gebeur in Lukas-Handelinge.

Meer as enige ander Evangelie word die sending aan die heidene ' $n$ integrale deel van die verhaalgang. Ons het reeds gewys op Hand 10. Maar reg aan die begin van die Lukasevangelie is dit reeds duidelik dat die heidene ingeskryf is in die plan van God met Jesus. Jesus se geslagsregister loop byvoorbeeld tot by Adam, en nie soos die Matteusevangelie net tot by Abraham nie. So word Jesus as behorende tot die hele menslike geslag voorgestel. Hy is redder van almal, nie net van die Jode nie. En Lukas is die enigste wat Jesus se verwerping deur sy tuisdorp en die gunstige reaksie van die heidene vooropstel in sy Evangelie. Anders as Markus en Matteus plaas hy hierdie gebeure aan die begin van Jesus se bediening, dit vorm die openingstoneel. Luk 4:16-30 word dus programmaties vir Jesus se ganse bediening: Sy tuisdorp soek bevoorregting by Jesus, maar Hy wys hulle op God se eintlike plan - hoe in Israel se verlede God sy guns aan die weduwee van Sarfat in Sidon en aan Naäman die Siriër bewys het, en nie aan die melaatses en weduwees van Israel nie. Die skokkende hiervan lei ons af uit die woedende reaksie van sy gehoor, die inwoners van Nasaret, tiperend van wat later in Lukas en veral Handelinge gebeur. Die grootste teenkanting kom nie van die kant van die Romeine nie, maar van die Jode.

Verder, Lukas bied die uitstuur van die dissipels so aan dat dit, anders as by Matteus, laat deurskemer dat dit nie net gaan oor 'n sending aan die Jode nie. In Luk 10:1-16 laat Lukas bv Matteus se verwysing weg dat die dissipels net na die verlore skape van Israel moet gaan en nie op die pad van die heidene nie. En daarby is Lukas die enigste een wat noem dat Jesus twee en sewentig ander uitgestuur het. Die getal klop met die twee en sewentig nasies van die wêreld, na aanleiding van die volkeretafel van Gen $10^{7}$ (Grundmann 1969:207). In hierdie sending aan die Jode word die heidene dus reeds op subtiele wyse ingeweef in die verhaalgang van Lukas.

En dan word ' $n$ heiden tot voorbeeld vir Israel voorgehou. So word van die Romeinse offisier in Luk 7 gesê, nadat dié hom volledig gewerp het op Jesus se gesagswoord om sy slaaf te genees, dat Jesus in die hele Israel nie so 'n geloof teëgekom het nie. Wie eers outsiders was, word nou insiders, tot beskaming van Israel. Hierdie gedagte word verder gevoer in Hand 15, by die waterskeidingsvergadering van die apostels, wanneer dit duidelik word dat die heidene nie eers Jode hoef te word om eg tot die volk van God te behoort nie. Die belangrike vereistes wat altyd gegeld het vir die heidene as hulle Joodse proseliete wou word, val nou weg. Hulle hoef nie meer die wet van Moses rondom die besnydenis of die reinheidswette - so belangrik vir ' $n$ heiligheidskultuur - na te kom nie. ${ }^{8}$ Geloof in Christus is voldoende. So word die heidene in eie reg volwaardige lede van die Godsvolk, en nie via hulle verbondenheid aan Israel nie. 'n Slag vir die Joodse ego, maar 'n bewys van God wat nie 'n aannemer van die persoon is nie, wat nie onderskeid tref tussen Jood en heiden nie, maar almal op gelyke grondslag beoordeel, omdat Hy die hartekenner is.

\subsection{Die Samaritane}

772 volgens die LXX, 70 volgens die Hebreeuse teks.

8 Oënskynlik lyk dit of die voorwaardes wat steeds aan die heidene gestel word (die sg aposteldekreet van Hand 15:20,29), nl om nie vleis te eet wat aan 'n afgod geoffer is nie, om onsedelikheid te vermy, en nie bloed of verwurgde diere te eet nie 'n streep trek deur die ooreenkoms wat bereik is. Die aposteldekreet tas egter nie die grondliggende afskaffing van die wet van Moses vir die heidene aan nie. Dit staan eerder in die teken van kompromissluiting waar van die heidene sekere toegewings gevra word om die gevoelens van die Joodse Christene in ag te neem. Dis nie die wet van Moses wat weer by die agterdeur ingevoer word nie, maar die wet van die liefde wat seëvier (so De Villiers 1987:41-42,45; Van Zyl 1989:59). 
Die onmin en konflik tussen die Jode en die Samaritane is goed gedokumenteer in die Nuwe Testament (Matt 10:5; Luk 9:51-56; Joh 4:9; 8:48). Die Samaritane was die oorblyfsel van die ou Noordelike Ryk van Israel of die sg Tien Stamme-ryk wat reeds in die 8e eeu vC na Assirië in ballingskap weggevoer is. Maar anders as hulle broers in die suide twee eeue later, was daar nooit 'n terugkeer na Palestina nie. Tog het dié wat nie weggevoer is nie die godsdiens en tradisies van hulle voorvaders voortgesit. Hulle het, soos die latere Sadduseërs, slegs die vyf boeke van Moses as gesaghebbend beskou, maar het hulle eie aanbiddingsplek op die Gerisimberg naby Sigem verkies. ' $n$ Tempel is ook later hier gebou. Dit was ' $n$ taamlike punt van irritasie by die Jode dat die tempel in Jerusalem nie deur die Samaritane as sentrale heiligdom erken is nie. Ondertrouery met ingevoerde volke in Noord-Israel ná die wegvoering van die boonste laag van die bevolking was aan die orde van die dag (Gerleman 1969:348). Daarom dat die Samaritane deur die Judeërs in die suide as ' $n$ bastervolk beskou is, en gevolglik onrein. Reeds teen die tyd van die Suidelike Ryk se terugkeer na Jerusalem ná die Babiloniese ballingskap was die tweespalt tussen Jode en Samaritane duidelik toe Sanballat, waarskynlik die goewerneur van Samaria, smalend was oor die herbou van die mure van Jerusalem, en dit duidelik gestel is deur Nehemia dat Sanballat geen aandeel of reg in Jerusalem het nie (Neh 2:19-20). Onnodig om te sê dat teen die tyd van die Nuwe Testament die Samaritane lank nie meer deur die Jode as volksgenote beskou is nie, ten spyte van hulle gesamentlike aartsvaderlike voorgeslag. Die Samaritane is verag as ' $n$ gemengde groep met hulle eie godsdiens. Die Jode het dit ook vermy om deur die Samaritaanse gebied wat tussen Judea in die suide en Galilea in die noorde gelê het, te beweeg. Hulle het liefs 'n omweg gevolg aan die oorkant van die Jordaanrivier. As jy iemand wou beledig, het jy hom ' $n$ Samaritaan genoem, wat so ongeveer gelyk was aan "demoonbesetene" (vgl Joh 8:48). ${ }^{9}$

Jesus toon egter 'n verstommende openheid teenoor die Samaritane. ${ }^{10}$ Wat al klaar ongewoon was, is wanneer Lukas dit duidelik stel dat Jesus en sy dissipels deur Samaria gereis het. Die dissipels se humeure wou-wou opvlam toe ' $n$ Samaritaanse dorp se inwoners Jesus nie wou ontvang nie, maar Jesus het sy dissipels tereggewys en verbied om te bid vir die verdelging van die dorp (Luk 9:52-55). By 'n ander geleentheid het Jesus op die grens tussen Samaria en Galilea tien melaatses genees. Net een het kom dankie sê, en dan merk Lukas pertinent op dat die man 'n Samaritaan, 'n nie-Jood, was. Hierdie man het aan God die eer gebring en het op daardie dag redding ontvang (Luk 17:18-19). Verder, die bekende gelykenis van die barmhartige Samaritaan is seker die mees beskamende preek van Jesus om die skynheiligheid van die Jode aan die kaak te stel. Nie die Leviet of priester, wat veronderstel was om die wet te ken, bied hulp aan die verwonde langs die pad nie, maar ' $n$ veragte Samaritaan. Ondanks al die beskuldigings deur die Jode dat die Samaritane God verkeerd dien en op 'n onregmatige plek aanbid, wys die Samaritaan dat hy meer verstaan van die hart van God as die geestelike elite van die Jode. Dit moes ' $n$ bitter pil vir die Joodse gehoor gewees het om te sluk. En dan lees ons in Hand 8 van die suksesvolle bediening van Filippus in die Samaritaanse gebied. Baie Samaritane het die woord van God aanvaar en ook die Heilige Gees ontvang, teken daarvan dat hulle op gelyke vlak met hulle Joodse eweknieë deur God begenadig is. ${ }^{11}$

Lukas-Handelinge beskryf dus hoe eeu-oue vooroordele, wanpersepsies en haat tussen Jode

9 Vir 'n goeie oorsig oor die herkoms, lotgevalle en gebruike van die Samaritane, kyk Pelser 1997.

10 Vergelyk Marshall (1970:140) se opmerking: "For Luke the compassion of Jesus did not stop at the boundary of Israel. Although it is well attested historically that for the most part Jesus confined His mission to the Jews, Luke indicates that there were also a place for the Samaritans, the particular enemies of the Jews, in His concern."

11 Die herhaaldelike uitstorting van die Heilige Gees in Handelinge 2, 8, 10 en 19 onderstreep juis die gedagte dat die vervulling van die belofte van Joël 2:28-32 (vgl Hand 2:17-21) nie net vir die Jode in vervulling gaan nie, maar dat ook die heidene op hierdie manier deel van die Godsvolk word. (Vir 'n breedvoeriger uiteensetting van hierdie saak, kyk Van Zyl 1997.) 
en Samaritane deur die evangelie gestroop word van hulle houvas. God is inderdaad die Een wat nie ' $n$ aannemer van die persoon is nie. Hy ken en sien die hart raak. Hy laat jou met nuwe oë na die ander kyk.

\subsection{Randfigure van die samelewing}

Binne die Joodse samelewing was daar allerlei groepe wat deur die heiligheidskultuur van die dag na die rand van die samelewing uitgestoot is, sommige openlik, ander meer subtiel. LukasHandelinge wys egter dat Jesus ook na hierdie groepe uitreik, hulle nood raaksien, en hulle in ere herstel as volwaardige lede van die Joodse geloofsgemeenskap. Ons kyk nou hierna.

\subsubsection{Armes}

Hierbo is na die programmatiese aard van Jesus se optrede in Luk 4:16-30 verwys. In sy "intreepreek" tipeer Jesus sy bediening met die woorde van Jes 61:1-2. Hy sê dat sy bediening daarin bestaan om die evangelie aan die armes te bring. Wie was die armes (ptōchoi / $\pi \tau \omega x o i)$ ?

Dis nie so maklik om hierdie groep te identifiseer nie. Green (1995:81-82) wys daarop dat in sewe van die tien voorkomste van die woord ptōchos / $\pi \tau \omega x o ́ c$ in Lukas dit in lyste voorkom saam met ander begrippe soos gevangenes, blindes, verdruktes, hongeres, treurendes, vervolgdes, blindes en verminktes $(4: 18 ; 6: 20 ; 7: 22 ; 14: 13 ; 14: 21 ; 16: 20,22)$. In ses van hierdie lyste staan "armes" eerste, en in een in die beklemtoonde laaste posisie. Wat duidelik is, is dat dit in die armes eerstens om letterlik armes gaan, maar dat dit verder ' $n$ wyer groep mense insluit wat vanweë hulle sosiale stand, siekte of gestremdheid na die rand van die samelewing uitgeskuif is. Die heersende heiligheidskultuur het veroorsaak dat hulle nie langer in tel was nie; daar is op hulle neergesien en hulle is effektief uit die religieuse gemeenskap uitgesluit. ${ }^{12}$

Verder word die armes gekontrasteer met die rykes (Green 1995:82). Die rykes is die mense wat volgens Lukas 12:16-21 en 16:19-31 hulle roeping versaak het teenoor die armes, ten spyte van hulle uitgebreide bronne. In 14:12 word aan die rykes gesuggereer dat hulle nie van hulle familie en "ryk bure" na hulle feesmaaltye moet nooi nie, maar eerder die armes, kreupeles, verlamdes en blindes. So gesien is "ryk" nie net 'n ekonomiese term nie, maar verwys dit na mag en invloed. En armoede is nie net gebrek aan geld nie, dis ook 'n sosiaal-religieuse kategorie wat totale uitsluiting en magteloosheid versinnebeeld.

Wanneer Lukas-Handelinge Jesus dus voorstel as die bringer van goeie nuus aan die armes, het die leser sy ore gespits. Hier is weer een van daardie verrassings wat ons in Lukas-Handelinge aantref. Lukas verwys naamlik na 'n omkeer van rolle wat plaasvind. So sing Maria ook in haar loflied (1:52-53): "Maghebbers word van trone afgeruk en geringes verhoog; behoeftiges word oorlaai met goeie gawes en rykes met leë hande weggestuur." Jesus het inderdaad gekom om die genadejaar van die Here aan te kondig (4:19). Dit verwys na die sg jubeljaar van die Ou Testament: elke 50e jaar was dit die veronderstelling in Israel dat grond weer na die oorspronklike eienaar moes terugkeer. Hier kondig Jesus dus aan dat daar 'n geestelike restourasieproses aan die gang gesit word met sy bediening waarvolgens mense se status herstel word as kinders van God (Nielsen 1986:136). God is nie net die God van rykes nie, maar ook van die armes. Diegene wat tans dink dat hulle in die sentrum van God se guns verkeer, mag hulleself hierna in die buitenste duisternis bevind, en omgekeerd, dié op die rand van die samelewing, in die boesem van Abraham.

Hierdie omkeer van rolle word treffend geïllustreer in die gelykenis van die ryk dwaas (12:1621), en die ryk man en Lasarus (16:19-31). Die ryk dwaas is selfvoldaan in sy welvaart: sy toekoms is verseker; al wat nou vir hom oorbly, is om dit te geniet. En dan hoor hy die ontstellende woorde: nog in dieselfde nag sal hy sterf, en wie sal dan sy rykdom geniet? Beslis nie hy nie. So

12 Vir 'n oorsig oor die posisie van die armes in Palestynse Jodedom, kyk Bammel 1968:899-902. 
ook die ryk man en Lasarus. Die ryke geniet elke dag oorvloed, en Lasarus sit by die einste ryke se hek en hoop op iets wat van die tafel afval. Maar by Lasarus en die ryke se sterwe word die rolle omgekeer: nou is die ryke in die grootste ellende, en Lasarus beklee 'n ereplek by Abraham. Die punt is duidelik: rykdom is nie noodwendig bewys van God se seën nie. Die ryk man se bestemming in die hiernamaals bevestig dit. En Lasarus wat op aarde beskou is as buite die koninkryk van God, se status word omgekeer: hy beklee nou 'n ereplek by God. Ons wat bekend is met die evangelieverhaal het al gewoond geraak aan hierdie soort anomalieë in die evangelie. Maar binne die heiligheidskultuur van die eerste eeuse Jodedom moes hierdie gelykenisse soos heiligskennis geklink het. Dis ongehoord, en tog is dit presies wat Lukas sê hoe God se heilsekonomie werk.

\subsubsection{Tollenaars}

Nog 'n kategorie wat binne die destydse heiligheidskultuur hulleself op die rand van die sosiaalreligieuse gemeenskap bevind het, was die tollenaars. Hulle was wel Jode, maar is vanweë hulle beroep verag en sosiaal-religieus geostraseer. Die tollenaars is mense wat belasting-franchises by die Romeinse owerheid gekoop het. Hulle het dan namens die Romeine belasting ingevorder by die Jode, die verpligte bedrag aan die Romeine betaal en die res - hulle kommissie - in hulle sak gesteek. Om twee redes was hulle verag: weens hulle geheul met die Romeinse onderdrukkers, en omdat hulle woekerwinste gemaak het. Hulle het veel meer as waarop hulle geregtig was van hulle mede-Jode geëis. (lets hiervan is sigbaar in Johannes die Doper se raad aan die tollenaars, Luk 3:12-13, asook in Saggeus se reaksie, 19:8.)

In Lukas-Handelinge reik Jesus ook na hierdie groep uit. Lukas 18:9-14 verhaal Jesus se gelykenis van die Fariseër en die tollenaar wat in die tempel gaan bid het. Hulle verteenwoordig uiterste pole van die Joodse godsdienstige gemeenskap: die Fariseër die toonbeeld van godsdienstige geregtigheid. Trots vertel hy vir God hoe ' $n$ fyn gelowige hy is: hy doen alles wat die wet van Moses vereis, en verder distansieer hy hom van almal wat nie deel het aan die koninkryk van God nie - diewe, bedrieërs, egbrekers en tollenaars. Die tollenaar, daarenteen, weet dat hy wegwerplik is voor die aangesig van God. Hy stel homself ook aan God voor met die naam waaronder hy bekend is in die samelewing: sondaar. Desnieteenstaande beroep hy hom op die genade van God. En dan, weer eens, die verrassende, die skokkende: dis die tollenaar, nie die Fariseër nie, wat as die godsdienstig geregverdigde (dikaios) huiswaarts keer. Weer die omkeer van rolle: die een wat dink sy saak met God is reg, moet hoor dit is nie so nie; die een wat weet sy saak is allesbehalwe reg, word regverdig verklaar.

Die gebeure rondom Saggeus in Lukas 19:1-10 bevestig die gelykenis hierbo, dat godsdienstige randfigure dit ook maak by God. Saggeus is hooftollenaar en 'n ryk man. ${ }^{13}$ Maar ongeag hierdie "status" het hy andersins geen status gehad nie. Sosiaal-religieus was hy nie deel van die hoofstroom nie. In terme van die heiligheidskultuur van daardie tyd was hy 'n outsider (Moxnes 1988:164). Ná sy ontmoeting met Jesus hoor hy egter dat hy ook 'n kind van Abraham is. Nie net die geestelike elite maak dit by God nie, maar ook 'n gemarginaliseerde tollenaar. Hy bevind hom nie meer op die rand nie, maar in die sentrum van God se heil; hy het redding gevind. Geen wonder nie dat hy besluit om almal by wie hy onregmatig geld gevat het, viervoudig te vergoed.

\subsubsection{Vroue}

13 Die term architelōnēs, hooftollenaar, is problematies. Dit kom nie elders in die NT of in ander Griekse geskrifte voor nie. Die term kan óf beteken dat ander tollenaars vir Saggeus gewerk het (Ellis 1974:220), óf dat hy hoof van die tollenaars in Jerigo was (Grundmann 1969:359), of dat hy saam met vennote groter kontrakte aangegaan het (Michel 1972:98vn105), óf dit is ' $n$ ironiese manier om hom as ' $n$ baie groot sondaar aan te merk, vanweë sy rykdom (sy groot rykdom maak hom ook 'n aartssondaar (Nolland 1993:904-905). 
Vroue in die antieke samelewing het hulle in 'n streng patriargale samelewing bevind. Binne hierdie opset kon hulle slegs ' $n$ beperkte rol in die samelewing speel. Hulle eintlike plek was in die huis - as vrou en moeder. In die Jodedom was daar ook allerlei bykomende vooroordele teen die vrou, soos dat sy die oorsaak van sonde is (via die paradysverhaal), ${ }^{14}$ dat sy sekere tye van die maand kulties onrein is, dat sy onbetroubaar is en haar getuienis nie in die hof aanvaar word nie, ${ }^{15}$ dat sy nie nodig het om die wet te bestudeer nie en daarom ook nie aktief kan deelneem aan die tempelkultus of die sinagogale dienste nie (Lohse 1976:149). Vir alle praktiese doeleindes het sy nie in eie reg 'n sosiale en religieuse status gehad nie. Haar status het sy bekom via haar verbintenis met 'n man - pa, man of broer. Geen wonder nie dat Rabbi Juda in die tweede eeu nC die Here gedank het dat hy nie as ' $n$ heiden, ' $n$ ongeletterde of ' $n$ vrou geskape is nie (vgl Lohse 1976:150).

Teen hierdie agtergrond is die posisie wat Jesus aan die vrou toeken merkwaardig. Haar status word van randfiguur na die sentrum verplaas. So vertel Lukas die geboorte van Jesus nie soos Matteus vanuit die perspektief van Josef nie, maar vanuit Maria s'n. In Matteus voer die engel die gesprek met Josef, maar in Lukas is dit met Maria. Dit is asof God in private onderhandeling met Maria is. In terme van die destydse eer en skande-kultuur waar afstamming en status baie belangrik was, het Maria nog nie enige status gehad nie. Sy was (nog) nie getroud met Josef nie, en sy kom van Nasaret in Galilea, ver van die sentrum van Joodse heiligheid, Jerusalem. Sy is wel ' $n$ familielid (suggenis) van Elisabet, wat ' $n$ dogter van Aäron was, maar suggenis is ' $n$ baie vae statusaanduiding (so Nolland 1989:56; Green 1995:142). Verder is sy 'n "jong maagd," wat volgens destydse opvattings beteken het dat sy so 12-13 jaar oud was. Wat ouderdom betref, geniet sy dus nog nie dieselfde status as wat Elisabet het nie. Laasgenoemde was saam met haar man reeds gevorderd in jare, en dit bring hierdie egpaar statusgewys in die buurt van Abraham en Sara wat ook eers op gevorderde leeftyd ouerskap ervaar het. Lukas teken Maria dus doelbewus as statusloos, omdat hy klem wil lê daarop dat sy haar status direk van God ontvang. Met haar woorde "Ek is tot beskikking van die Here. Laat met my gebeur wat u gesê het" (1:38), maak sy daarop aanspraak om aan die huishouding van God te behoort. Dít is haar familie. So begin Lukas om status anders te definieer: nie in terme van afstamming of sosiale agtergrond nie, maar in terme van jou verhouding met God (Green 1995:142). Maria vervul dus ' $n$ ekklesiologiese funksie in die proloog van Lukas (Schnelle 2009:516). Sy verteenwoordig daardie Israel waaruit die kerk uiteindelik groei. Die belofte omtrent die Messias word aan haar toevertrou en sy reageer gelowig daarop deur haar tot beskikking te stel vir God en te glo dat sy beloftes in vervulling sal gaan $(1: 38,45)$. In Handelinge $1: 14$ is sy dan ook deel van die gelowiges wat volhard in die gebed.

In Lukas 1-2 is dit opvallend dat vroue 'n prominente rol speel in die aankondiging van Jesus en Johannes die Doper se geboorte. Vroue tree in pare op saam met mans: Sagaria en Elisabet (mbt Johannes) en Josef en Maria (met betrekking tot Jesus). Daarnaas kry Sagaria se loflied (1:67-79) 'n parallel in Maria se loflied (1:46-55). Verder is dit nie net Simeon wat teenwoordig is by Jesus se besnydenis nie, maar ook Anna, 'n profetes. Soos Simeon word sy voorgestel as iemand wat vroom is en wat weet waarom dit in die seuntjie Jesus se geboorte gaan. Met hierdie vroue wou Lukas twee dinge doen: hulle op gelyke vlak stel met mans, en hulle van meet af aan getuies maak van die koms van Jesus. Die getuieniskarakter van vroue se optrede word ook onderstreep deur die opstandingsberig. Dit is vroue wat die leë graf sien, die engele se boodskap

141 Timoteus 2:14-15 verteenwoordig iets van hierdie opvatting: dat dit nie Adam was wat verlei is nie, maar die vrou, en dat sy so sonde in die wêreld gebring het. Hierdie gedagte word eksplisiet verwoord deur Jesus Sirag 25:24 (aangehaal deur Dibelius \& Conzelmann1972:47vn23).

15 Iets hiervan skemer deur in Lukas 24:11,22 waar die dissipels nie die vroue se berig oor die opstanding van Jesus wou glo nie. 
hoor, die woorde van Jesus onthou en met die dissipels daaroor praat. Die vroue se bereidheid om Jesus se opstanding te glo en daarvan te getuig, word gekontrasteer met die dissipels se negatiewe optrede wat dit alles as onsinnige praatjies afmaak (24:11). Eers toe dit deur ander mans as betroubaar bevestig is, glo hulle (24:34-35) (Green 1995:93). Hierdie voorstelling van die vroue is merkwaardig as in gedagte gehou word dat vroue nie as betroubare getuies beskou is nie. Die vroue vorm dus saam met hulle manlike eweknieë die ekklesiologiese basis vir die latere kerk. Die kerk bestaan nie net uit mans nie, vroue is gelykwaardige lede. Hierdie insig word later bevestig in die gebeure rondom Marta en Maria (Luk 10:38-42). Marta is vies omdat Maria haar nie met die bediening van die ete help nie (die tradisionele rol van die vrou!), maar Jesus neem Maria se plek aan sy voete in beskerming. Daar is nie net plek vir tradisionele rolle nie, maar ' $n$ nuwe rol word aan die vrou toegeken: een wat onderrig word en haar volwaardige plek in die kerk as dissipel van Jesus inneem.

Belangrik is ook die funksie wat vroue vervul het as beskermvroue van Jesus se bediening. Ons lees in Lukas 8:1-3 van vroue wat saam met Hom en die dissipels gereis het en uit eie middele vir hulle gesorg het. Dit klop ook met die sakevrou, Lidia, van Handelinge 16:14-15 wat nie net tot geloof kom nie, maar vir Paulus en sy reisgenote finansieel ondersteun. Hierdie vroue wat finansiële ondersteuning gee aan Jesus en die kerk se bediening verteenwoordig ' $n$ model van entrepreneuriese optrede deur vroue wat bevestig dat Lukas ' $n$ hoë premie plaas op die selfstandige bydrae van die vrou binne die geloofsgemeenskap.

Afgesien van bostaande is daar ook nog ander gevalle waar vroue voorgehou word as voorbeelde van vroomheid en geloofsvolharding: In Lukas 18:1-8 is dit die gelykenis van die weduwee wat volhardend haar lot by die ongenaakbare regter gaan bekla totdat aan haar gehoor gegee word. En in 21:1-4 word vertel van die weduwee wat haar hele vermoë in die tempelskatkis gegooi het.

As daar een ding is wat Lukas-Handelinge goed regkry, is dit om die vrou in die kollig te plaas. Sy is nie meer ' $n$ randfiguur nie, maar ' $n$ volwaardige lid van die gemeente.

\subsubsection{Sondaars}

Dit het hopelik reeds duidelik geword dat die term "sondaar" 'n baie spesifieke konnotasie binne ' $n$ heiligheidskultuur het. Dit verwys na hulle wat na die oordeel van die godsdienstige elite nie voldoen aan die standaarde van geregtigheid soos dit voorgehou is vanuit die wet van Moses nie. "Sondaars" is dus nie altyd 'n gefikseerde sosiale groep, soos "tollenaars" nie, maar sny oor verskillende sosiale grense heen. Dit verwys na almal wat weens hulle status en optrede deur die heiligheidskultuur na die rand van die geloofsgemeenskap gedwing is. Tipiese "sondaars" sou wees: diegene buite die verbondsvolk, soos heidene en Samaritane; hulle wat 'n flagrante immorele ly, soos moordenaars, rowers, diewe, prostitute, egbrekers, bedrieërs; en hulle wat 'n oneerbare beroep volg wat hulle kan verlei tot oneerlikheid, soos tollenaars (vgl Luk 18:13) (Rengstorf 1964:327). Dit is verder bekend dat rabbi's ook veragting gekoester het vir beroepe soos herders en leerlooiers (vgl Grundmann 1969:81-82; Haenchen 1971:340vn1). Die heiligheidskultuur het egter so 'n geweldige impak op gewone "goeie" mense gehad, en die teenwoordigheid van die geestelike elite was so kragtig dat mense maklik geestelik minderwaardig gevoel het en hulleself as sondaars gereken het. Veral in sekere omstandighede. So word Petrus oorweldig deur die wonder van die groot visvangs en hy versoek Jesus om liewer van hom af weg te gaan omdat hy, Petrus, 'n "sondige mens" is (Luk 5:8). Hy besef hy is in die teenwoordigheid van lemand wat met die krag van God optree, en daarom voel hy homself onwaardig. Lukas gebruik dus hierdie term om nie net die religieuse randfigure binne die heiligheidskultuur aan te dui nie, maar ook by die algemeen menslike kondisie van sondigheid uit te kom wat redding op 'n diep geestelike vlak benodig. 
As dit dus gaan oor die herstel van status van die randfigure van die destydse samelewing arriveer ons hier by die mees omvattende kategorie: sondaars. Lukas se hantering van hierdie begrip is so dat almal - ook die geestelike elite - sou besef het dat hulle sondaars is en nood het aan redding. Daar steek dus diepe ironie daarin wanneer Jesus op die vraag van die Fariseërs en skrifgeleerdes: "Waarom eet en drink julle saam met tollenaars en sondaars?" antwoord: "Ek het nie gekom om regverdiges te roep nie, maar sondaars tot bekering " (5:32). Oënskynlik klink dit of Jesus se missie nie op hulle van toepassing is nie. Maar as die hele Lukas-Handelinge verhaal in oënskou geneem word - hoe redding nie beteken dat regverdiges geskei word van sondaars nie, maar dat sondaars deel word van die regverdiges, en dat daar eintlik nie 'n onderskeid tussen die twee kategorieë is nie (soos Paulus in Rom 3:23 onderstreep), behoort die Fariseërs uiteindelik die boodskap te gekry het dat bekering ook - juis! - vir hulle bedoel was. Dit sou egter slegs gebeur het vir wie oë het om te sien en ore het om te hoor.

Dat die Fariseërs wou skeiding maak en Jesus wou bymekaar bring, word treffend geïllustreer in die gebeure rondom die sondige vrou - sondaar - van Lukas 7:36-50. Hierdie vrou het by Jesus se voete gesit en huil, sy voete met haar trane gewas, met haar hare afgedroog en toe met reukolie gesalf. Simon, Jesus se Fariseër-gasheer, dink toe by homself dat as Jesus 'n profeet was, Hy sou geweet het dat die vrou 'n sondares was en - volgens die heiligheidskultuur - nie moes toegelaat het dat sy aan Hom raak nie. Wat Simon egter nie raaksien nie, is die kernwaardes van berou, liefde en sondevergiffenis wat die verhouding met God herstel. Simon dring eerder aan op 'n geregtigheid wat sigself distansieer van 'n ongewenste sondaar, 'n optrede wat lynreg teen die bedoeling van God ingaan (deSilva 2004:324). Jesus verduidelik toe hierdie beginsel aan hom aan die hand van 'n gelykenis, ${ }^{16}$ waarvan die punt is dat die verhouding met God deur berou en liefde gekonstitueer word - waarvan die vrou oorvloedig bewys gelewer het - en nie bepaal word deur jou afkoms, sosiale status of (im)morele lewe nie. Daarom dat Jesus sy missie teenoor haar kon volbring deur vir haar te sê: "Jou sondes is vergewe ... jou geloof het jou gered, gaan in vrede" (7:48-50). En met hierdie woorde het Jesus haar status van randfiguur tot kind van God omgekeer.

\section{UITKOMS}

Die vraag wat nou oorbly, is watter bydrae die uiteensetting hierbo lewer tot 'n teologie van respek. Hoe laat Jesus via Lukas-Handelinge ons met nuwe oë na ander kyk? Die volgende kan aangestip word. Elkeen van hierdie insigte lê aan die wortel van 'n ingesteldheid van respek teenoor die ander.

\subsection{Nuwe oë sien die ander as volwaardige medemens}

'n Heiligheidskultuur vervreem mense van mekaar. Geykte wanpersepsies ontstaan wat oor dekades en selfs eeue tot ondeurdringbare skanse tussen mense verhard. Dit lei tot 'n diep verdeelde samelewing en demonisering van die ander. Kwetsende benamings ontstaan. "Samaritaan" is gelyk aan "demoonbesetene". Almal wat nie voldoen aan jou standaarde nie is "sondaars" of "agterlikes" ("die volk van die land"). En om 'n bladsy uit Paulus se boek te neem: Jode verwys na Grieke as "onbesnedenes" (Ef 2:11), en Grieke op hulle beurt na ander as "barbare." En waar geykte wanpersepsies en kwetsende benamings praktyk is, daar word die ander ver-ding-lik, en waar ander "dinge" is, daar heers disrespek, want jy hoef nie "dinge" met respek te behandel nie. Maar Lukas-Handelinge wys hoe Jesus deur hierdie skanse breek

16 'n Krediteur het twee skuldenaars. Die een skuld hom 500 dinarii, die ander 50. Hy skeld al twee hulle skuld vry. Wie van die twee het hulle krediteur die meeste lief? Uiteraard die een wat die meeste geskuld het. 
en die ander herstel as volwaardige medemens wat ons respek waardig is. Sy optrede dring ons om met nuwe oë na mekaar te kyk. 'n Tollenaar kan ook kind van Abraham of regverdige wees, 'n Samaritaan kan 'n toonbeeld word van barmhartigheid, 'n statuslose jongmeisie kan 'n begenadigde van God en mededissipel word, en 'n sondares 'n geliefde van God.

\subsection{Nuwe oë sien dat almal gelyke status voor God het}

Verskille tussen mense kan daartoe lei dat sekere mense hulleself inherent meerderwaardig teenoor ander voel. Hulle het groter aanspraak op God se seën as ander. Maar God maak nie onderskeid tussen mense nie. Alle mense geniet gelyke status voor Hom. Hy sien nie aan wat voor oë is nie, maar Hy is die hartekenner wat op ander gronde oordeel as mense. Ons het nuwe oë nodig om te sien dat ons almal dieselfde status geniet, almal dieselfde behoeftes en nood het, en almal ewe skuldig en ewe begenadig voor God staan. Ons hoef daarom nie mekaar se respek te verdien nie. Respek vir die ander word opgeroep gewoon omdat ons almal voor God gelyk is en dieselfde status geniet.

\subsection{Nuwe oë sien die ander as ' $n$ mens in eie reg}

Ander hoef nie eers soos ons te word voordat hulle ons respek waardig is nie. My groep is nie die norm of kriterium waarvolgens ander aanvaarbaar is nie. Dít leer Hand 15 ons. Die heiden word in eie reg en op "eie meriete" deel van die Godsvolk, nie via hulle verbintenis met die ou Godsvolk, die Jode, nie.

\subsection{Nuwe oë sien die eie verantwoordelikheid raak}

Mense in bevoorregte en magsposisies het 'n besondere verantwoordelik om oor grense heen te beweeg ten einde respek te betoon. Mense wat vir lank in minderwaardigheid verkeer en gewoond is aan afbrekende gedragspatrone teenoor hulle vind dit moeilik om uit hierdie bestaan los te breek. Hulle het nie altyd die insig of middele om dit te doen nie. Vroue van destyds het geen manier gehad om aan hulle minderwaardige posisie te ontsnap nie. God moes in Jesus na hulle uitreik. Die ryk man moes na Lasarus omsien, maar het sy verantwoordelikheid versaak. Lasarus het nie 'n manier gehad om respek af te dwing nie. In oud-Israel was dit juis die koning se verantwoordelikheid om as ' $n$ herder vir sy volk op te tree, om te versorg en te lei. In die tyd van Jesus was dit die geestelike leiers se taak, maar hulle het eerder die verwydering geperpetueer en nog groter laste op die geestelike onderdane gelê. 'n Situasie van ongelykheid plaas dus groot verantwoordelikheid op hulle wat die insig het en oor die middele beskik om 'n verskil te maak.

\subsection{Nuwe oë sien raak dat situasies kompleks kan wees}

Die groot aantal diverse groeperinge in die destydse Joodse samelewing wys hoe ingewikkeld dit soms is om onderlinge respek tussen groepe te laat groei. Hoe groter die diversiteit is, hoe versigtiger moet mens wees vir kitsoplossings. Die dinamika in onderlinge verhoudings in ' $n$ samelewing is dikwels kompleks en vra groot wysheid om 'n gedeelde basis vir onderlinge respek te kweek. Egte hartsverandering, wysheid en volharding is wat nodig is.

\subsection{Nuwe oë sien die potensiaal van nuwe lojaliteite raak}

Hoewel verskille tussen mense oor lang tye kan verhard, is dit nie onbeweeglike, ewige skeppingsordeninge nie. Verskille is vloeibaar. Wanneer met nuwe oë na ander gekyk word en mense mekaar se gelyke status voor God aanvaar en mekaar ontdek in elkeen se uniekheid en andersheid, kan daar beweging kom wat verskille relativeer en die skerp kante rond maak. Die tollenaar bly nie net tollenaar nie, maar word ontdek as kind van Abraham. Die sondige vrou 
bly nie sondares nie, maar word deel van die binnekring van begenadigdes. So ontstaan nuwe verbintenisse en lojaliteite wat óór voormalige vyandskap en hindernisse strek.

Kort saamgevat: Respek ontstaan wanneer ons met nuwe oë - God se oë - na die ander kyk. Respek vir die ander groei ten diepste uit die bekering tot die ander.

\section{GERAADPLEEGDE LITERATUUR}

Bammel, E 1968. s v ptōchos. TDNT.

deSilva, D A 2004. An introduction to the New Testament. Contexts, methods \& ministry formation.

Downers Grove: InterVarsity Academic.

De Villiers, P G R 1987. Die apostelkonvent (Handelinge 15), in Breytenbach, C (red), Eenheid en konflik, 23-47. Pretoria: N G Kerkboekhandel.

Dibelius, M \& Conzelmann, H 1972. The Pastoral Epistels. Philadelphia: Fortress. (Hermeneia.)

Du Rand, J A 1997. Die Esseners, Koemraangemeenskap en Terapeute, in Du Toit 1997b:291-299.

Du Toit, A B 1997a. Geloof en godsdiensbeoefening van die Vroegjodedom, in Du Toit 1997b:435-507.

Du Toit, A B (red) 1997b. Die leefwêreld van die Nuwe Testament. Halfway House, Johannesburg: Orion. (Handleiding by die Nuwe Testament II.)

Ellis, E E 1974. The Gospel of Luke. London: Oliphants. (NCB.)

Gerleman, G 1969. s v Samaritanen. Bijbels-Historisch Woordenboek IV.

Green, J B 1995. The theology of the Gospel of Luke. Cambridge: Cambridge University Press. (New Testament Theology.)

Grundmann, W 1969. Das Evangelium nach Lukas. Berlin: Evangelische Verlagsanstalt. (ThHzNT 3.)

Hartin, P 1998. Disciples as authorities within Matthew's Christian-Jewish community. Neotestamentica 32, 389-404.

Haenchen, E 1971. The Acts of the apostles. Oxford: Blackwell.

Hays, R B 1996. The moral vision of the New Testament. A contemporary introduction to New Testament ethics. New York: HarperOne.

Lindijer, C H 1990. Handelingen van de apostelen. II. Nijkerk: Callenbach. (PNT.)

Lohse, E 1968. s v prosōpolēmpsia ktl. TDNT.

Lohse, E 1976. The New Testament environment. London: SCM.

Meier, R 1965. s v katharos. TDNT.

Michel, O 1972. s v telōnēs. TDNT.

Moxnes, H 1988. The economy of the kingdom. Social conflict and economic relations in Luke's Gospel. Philadelphia: Fortress. (Overtures to Biblical Theology.)

Nielsen, J T 1986. Het evangelie naar Lucas. I. Nijkerk: Callenbach. (PNT.)

Nolland, 1989. Luke 1:1-9:20. Nashville: Thomas Nelson. (WBC 35a.)

Nolland, 1993. Luke 18:35-24:53. Dallas: Word Books. (WBC 35c.)

Pelser, G M M 1997. Die Samaritane, in Du Toit 1997b:509-517.

Rengstorf, K H 1964. s v hamartōlos. TDNT.

Schnelle, U 2009. Theology of the New Testament. Grand Rapids: BakerAcademic.

Simpson, D P 1966. Cassell's New Latin-English English-Latin Dictionary. $4^{\text {th }}$ Edition. Cassell: London.

Tannehill, R C 1990. The narrative unity of Luke-Acts. A literary interpretation. Volume 2: The Acts of the apostles. Minneapolis: Fortress.

Van Aarde, A G 1994. Kultuurhistoriese agtergrond van die Nuwe Testament. Die eerste-eeuse Mediterreense sosiale konteks. Pretoria: Kital.

Van Staden, P 1991. Compassion - the essence of life. A social-scientific study of the religious symbolic universe reflected in the ideology/theology of Luke. Pretoria: HTS Supplementum Series 4.

Van Zyl, H C 1989. ' $n$ Redaksie-historiese lesing van Handelinge 15:1-35. Acta Theologica 9, 43-61.

Van Zyl, H C 1997. Die doop en vervulling met die Heilige Gees - 'n Herwaardering, primêr vanuit Handelinge. Acta Theologica 17, 157-166. 


\section{TREFWOORDE}

\section{Respek}

Lukas-Handelinge

Heiligheidskultuur

Heidene

Samaritane

Tollenaars

Vroue

Sondaars

\section{KEY WORDS}

Respect

Luke-Acts

Culture of holiness

Gentiles

Samaritans

Tax-collectors

Women

Sinners

Kontakbesonderhede:

Prof HC van Zyl

Departement Nuwe Testament

Fakulteit Teologie

Universiteit van die Vrystaat

E-posadres:vzylhc@ufs.ac.za 